\title{
Use of the atmospheric generators for capnophilic bacteria Genbag-CO2 for the evaluation of in vitro Plasmodium falciparum susceptibility to standard anti-malarial drugs
}

Aurélie Pascual ${ }^{1,2}$, Leonardo K Basco ${ }^{2}$, Eric Baret ${ }^{1,2}$, Rémy Amalvict ${ }^{1,2}$, Dominique Travers ${ }^{1,2}$, Christophe Rogier ${ }^{1,2}$, Bruno Pradines ${ }^{1,2,3^{*}}$

\begin{abstract}
Background: The aim of this study was to evaluate the cultivation system in which the proper atmospheric conditions for growing Plasmodium falciparum parasites were maintained in a sealed bag. The Genbag ${ }^{\circledR}$ system associated with the atmospheric generators for capnophilic bacteria Genbag $\mathrm{CO}_{2}{ }^{\circledR}$ was used for in vitro susceptibility test of nine standard anti-malarial drugs and compared to standard incubator conditions.

Methods: The susceptibility of 36 pre-identified parasite strains from a wide panel of countries was assessed for nine standard anti-malarial drugs (chloroquine, quinine, mefloquine, monodesethylamodiaquine, lumefantrine, dihydroartemisinin, atovaquone and pyrimethamine) by the standard 42 -hour ${ }^{3} \mathrm{H}$-hypoxanthine uptake inhibition method using the Genbag $\mathrm{CO}_{2}{ }^{\circledR}$ system and compared to controlled incubator conditions $\left(5 \% \mathrm{CO}_{2}\right.$ and $\left.10 \% \mathrm{O}_{2}\right)$.

Results: The counts per minute values in the control wells in incubator atmospheric conditions $\left(5 \% \mathrm{CO}_{2}\right.$ and $10 \%$ $\mathrm{O}_{2}$ ) were significantly higher than those of $\mathrm{Genbag}^{\circledR}$ conditions (2738 cpm vs $2282 \mathrm{cpm}, \mathrm{p}<0.0001$ ). The geometric mean $\mathrm{IC}_{50}$ estimated under the incubator atmospheric conditions was significantly lower for atovaquone (1.2 vs $2.1 \mathrm{nM}, \mathrm{p}=0.0011$ ) and higher for the quinolines: chloroquine (127 vs $94 \mathrm{nM}, \mathrm{p}<0.0001$ ), quinine (580 vs $439 \mathrm{nM}, \mathrm{p}<0.0001$ ), monodesethylamodiaquine (41.4 vs $31.8 \mathrm{nM}, \mathrm{p}<0.0001$ ), mefloquine (57.5 vs $49.7 \mathrm{nM}, \mathrm{p}=$ 0.0011 ) and lumefantrine (23.8 vs $21.2 \mathrm{nM}, \mathrm{p}=0.0044$ ). There was no significant difference of $\mathrm{IC}_{50}$ between the 2 conditions for dihydroartemisinin, doxycycline and pyrimethamine.

To reduce this difference in term of anti-malarial susceptibility, a specific cut-off was estimated for each drug under $\mathrm{Genbag}^{\circledR}$ conditions by regression. The cut-off was estimated at $77 \mathrm{nM}$ for chloroquine (vs $100 \mathrm{nM}$ in $10 \% \mathrm{O}_{2}$ ), 611 nM for quinine (vs 800 nM), 30 nM for mefloquine (vs 30 nM), 61 nM for monodesethylamodiaquine (vs 80 nM) and $1729 \mathrm{nM}$ for pyrimethamine (vs $2000 \mathrm{nM}$ ).
\end{abstract}

Conclusions: The atmospheric generators for capnophilic bacteria Genbag $\mathrm{CO}^{\circledR}{ }^{\circledR}$ is an appropriate technology that can be transferred to the field for epidemiological surveys of drug-resistant malaria. The present data suggest the importance of the gas mixture on in vitro microtest results for anti-malarial drugs and the importance of determining the microtest conditions before comparing and analysing the data from different laboratories and concluding on malaria resistance.

\footnotetext{
* Correspondence: bruno.pradines@free.fr

${ }^{1}$ Unité de Recherche en Biologie et Epidémiologie Parasitaires, Institut de Recherche Biomédicale des Armées - antenne de Marseille, Marseille, France Full list of author information is available at the end of the article
} 


\section{Background}

Over the past 20 years, many strains of Plasmodium falciparum have become resistant to chloroquine and other anti-malarial drugs [1]. Since 2001, more than 60 countries have officially adopted artemisinin-based combination therapies (ACTs) for the treatment of falciparum malaria [2,3]. However, clinical failures or at least longer parasite clearance times with ACT have been described in Cambodia [4-7]. The emergence and spread of resistance to most of the anti-malarial drugs require intensive research into identifying molecular markers of resistance, as well as implementing in vitro and in vivo surveillance programmes, such as those supported by the Worldwide Antimalarial Resistance Network [8,9].

There are basically three approaches to assess antimalarial drug susceptibility of $P$. falciparum: assessment of therapeutic efficacy standardized by the World Health Organization (WHO) [10], in vitro assays and molecular markers of resistance.

In a number of laboratories surveying anti-malarial drug resistance, in vitro tests are performed using the uptake of a radiolabelled nucleic acid precursor $\left[{ }^{3} \mathrm{H}\right]-$ hypoxanthine as a marker of parasite growth [11]. Other non-radioactive methods can be used: the WHO schizont maturation test by optical microscopy (Mark III) with pre-dosed plates [12], which was based on the methods of Rieckmann et al [13] and Wernsdorfer [14], a flow cytometric analysis of propidium iodide incorporation into parasite, which permits a stage-specific evaluation of anti-malarial compounds [15], a fluorescent-based technique that uses SYBR green I which binds to DNA $[16,17]$, and colorimetric or enzymelinked immunosorbent assays (ELISA) to measure histidine-rich protein II (HRP2) $[18,19]$ or plasmodial lactate dehydrogenase enzyme (pLDH) [20,21].

Many factors induce high variations in $P$. falciparum growth and $50 \%$ inhibitory concentration $\left(\mathrm{IC}_{50}\right)$ values and influence the results of the chemosusceptibility tests [22], such as culture medium, initial parasitaemia, haematocrit, incubation time, time point when $\left[{ }^{3} \mathrm{H}\right]$-hypoxanthine is added, use of serum substitutes, storage conditions of sample, delay before cultivation of samples and atmosphere (gas mixtures).

Laboratories using isotopic microtest to monitor drug resistance work at different oxygen tensions: $3 \% \mathrm{O}_{2}$ [15], $5 \% \mathrm{O}_{2}[18,19], 10 \% \mathrm{O}_{2}$ [23,24], in candle jars $[20,25]$ (which corresponds to approximately $17-18 \% \mathrm{O}_{2}$ ) and $>20 \% \mathrm{O}_{2}[21,22]$ (in $\mathrm{CO}_{2}$ incubators). WHO recommends the use of a candle jar in their in vitro microtests (Mark III). Despite the varying culture conditions, many laboratories have adopted the same threshold for the resistance to anti-malarial compounds under different oxygen tensions. For example, our previous study has shown that the chloroquine $\mathrm{IC}_{50}$ values at $10 \% \mathrm{O}_{2}$ were significantly higher than those at $21 \% \mathrm{O}_{2}[26]$. Nevertheless, it seems that $\mathrm{O}_{2}$ concentrations between $1 \%$ and $17.5 \%$ do not affect the $\mathrm{IC}_{50}$ values of quinoline-containing anti-malarial drugs [27-29]. In contrast, the in vitro anti-malarial activity of some antibiotics was dependent on the $\mathrm{O}_{2}$ concentration [27].

The aim of this study was to evaluate a cultivation system in which the proper conditions of atmosphere for growing $P$. falciparum parasites were maintained in an air-tight sealed bag. The Genbag ${ }^{\mathbb{B}}$ system was initially designed as atmospheric generators for capnophilic bacteria. Genbag CO $2^{\circledR}$ (BioMérieux;Marcy l'Etoile, France) was used for in vitro susceptibility test of nine standard anti-malarial drugs, and the $\mathrm{IC}_{50} \mathrm{~S}$ were compared to those obtained with controlled incubator conditions $\left(5 \% \mathrm{CO}_{2}, 10 \% \mathrm{O}_{2}\right.$ and $\left.85 \% \mathrm{~N}_{2}\right)$.

\section{Methods}

\section{Strains of $P$. falciparum}

A total of 36 pre-identified parasite strains (well-characterized laboratory strains or strains obtained from isolates after growth in culture for an extended period of time) from a wide panel of countries were maintained in culture in RPMI 1640 (Invitrogen, Paisley, United Kingdom), supplemented with $10 \%$ human serum (Abcys S.A., Paris, France) and buffered with $25 \mathrm{mM}$ HEPES and $25 \mathrm{mM} \mathrm{NaHCO}$. Parasites were grown in type $\mathrm{A}^{+}$ human red blood cells under controlled atmospheric conditions that consisted of $10 \% \mathrm{O}_{2}, 5 \% \mathrm{CO}_{2}$ and $85 \%$ $\mathrm{N}_{2}$ at $37^{\circ} \mathrm{C}$ with a relative humidity of $95 \%$. All strains were synchronized twice with sorbitol before use [30]. Clonality was verified using PCR genotyping of polymorphic genetic markers $m s p 1, m s p 2$, and microsatellite loci [31,32]. Chloroquine-susceptible 3D7 clone and chloroquine-resistant W2 clone (MR4 Resource Center) were cultivated in the same conditions and assessed for drug susceptibility in 4 independent experiments.

\section{Drugs}

Chloroquine, quinine, dihydroartemisinin, pyrimethamine and doxycycline were purchased from Sigma (Saint Louis, MO). Monodesethylamodiaquine was obtained from the WHO (Geneva, Switzerland). Mefloquine was obtained from Roche (Paris, France). Lumefantrine was provided by Novartis Pharma (Basel, Switzerland), and atovaquone was from GlaxoSmithKline (Evreux, France). Chloroquine and pyrimethamine were dissolved and diluted in water to obtain final concentrations ranging from 5 to $3,200 \mathrm{nM}$ for chloroquine and 5 to $40,000 \mathrm{nM}$ for pyrimethamine. Quinine, monodesethylamodiaquine, mefloquine, dihydroartemisinin, atovaquone and doxycycline were first dissolved in methanol and then diluted in water to obtain final concentrations ranging from 5 to $3,200 \mathrm{nM}$ for quinine, 
1.56 to $1000 \mathrm{nM}$ for monodesethylamodiaquine, 3.2 to $400 \mathrm{nM}$ for mefloquine, 0.1 to $100 \mathrm{nM}$ for dihydroartemisinin, 0.3 to $100 \mathrm{nM}$ for atovaquone and 0.1 to $502 \mu \mathrm{M}$ for doxycycline. Lumefantrine was dissolved and diluted in ethanol to obtain final concentrations ranging from 0.5 to $310 \mathrm{nM}$.

\section{In vitro assay}

For in vitro isotopic microtests, $200 \mu \mathrm{L} /$ well of a suspension of synchronous parasitized red blood cells (final parasitaemia, $0.5 \%$; final haematocrit, $1.5 \%$ ) was distributed in 96-well plates predosed with anti-malarial drugs. Parasite growth was assessed by adding $1 \mu \mathrm{Ci}$ of tritiated hypoxanthine with a specific activity of $14.1 \mathrm{Ci} / \mathrm{mmol}$ (Perkin-Elmer, Courtaboeuf, France) to each well at time zero. The plates were incubated for $42 \mathrm{~h}$ at $37^{\circ} \mathrm{C}$ in controlled atmospheric conditions in incubator $(5 \%$ $\mathrm{CO}_{2}, 10 \% \mathrm{O}_{2}$ and $85 \% \mathrm{~N}_{2}$ ) and $\mathrm{Genbag}^{\circledR}$ with the atmospheric generators for capnophilic bacteria Genbag $\mathrm{CO} 2{ }^{\circledR}$ (two plates per sealed bag) (Figure 1). Immediately after incubation, plates were frozen and then thawed to lyse the erythrocytes. The contents of each well were collected on standard filter microplates (Unifilter GF/B; Perkin-Elmer) and washed using a cell harvester (Filter-Mate Cell Harvester; Perkin-Elmer). The filter microplates were dried, and $25 \mu \mathrm{L}$ of scintillation cocktail (Microscint O; Perkin-Elmer) were placed in each well. The radioactivity incorporated into the nucleotides of the parasites was measured with a scintillation counter (Top Count; Perkin-Elmer).

The drug concentration that inhibits $50 \%$ of parasite growth $\left(\mathrm{IC}_{50}\right)$ was designated as the concentration at which the tritiated hypoxanthine incorporation reached $50 \%$ of the total incorporation by the parasites in the drug-free control wells. The $\mathrm{IC}_{50}$ value was determined

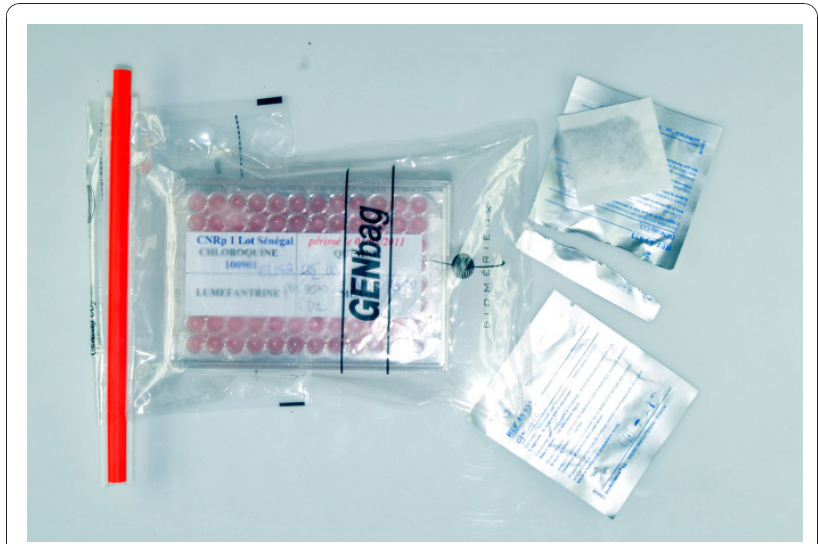

Figure 1 The Genbag ${ }^{\circledR}$ system associated with the atmospheric generators for capnophilic bacteria Genbag $\mathrm{CO}^{\circledR}$ with 2 plates in the specific sealed bag (picture $P$ Millileri). by non-linear regression analysis of log-based doseresponse curves (Riasmart, Packard, Meriden, USA).

\section{Statistical analysis}

Count per minute $(\mathrm{cpm})$ and $\mathrm{IC}_{50}$ were expressed as geometric means and 95\% confidence intervals. The differences between the data observed in the incubator and Genbag $^{\circledR}$ were analysed by a paired $t$-test. The correlation between the responses under two incubation conditions for each anti-malarial drug was estimated by the Pearson correlation coefficient $\mathrm{R}$. The same analyses were performed on $\mathrm{IC}_{50}$ strains/ $\mathrm{IC}_{50} 3 \mathrm{D} 7$ or $\mathrm{IC}_{50}$ strains $/ \mathrm{IC}_{50} \mathrm{~W} 2$ ratios calculated for each anti-malarial drug under the two conditions.

\section{Results}

A total of 1,098 drug-free control wells were analysed for each experimental condition. A significant difference was observed in the tritiated hypoxanthine uptake between the two conditions with 36 strains of $P$. falciparum (Table 1). The mean cpm values in the control wells under the controlled incubator conditions (5\% $\mathrm{CO}_{2}$ and $10 \% \mathrm{O}_{2}$ ) were significantly higher than those under Genbag $^{\circledR}$ conditions (2738 vs 2282 cpm, p value < 0.0001).

Compared to Genbag ${ }^{\circledR}$ conditions (5\% $\mathrm{CO}_{2}$ and $15 \%$ $\mathrm{O}_{2}$ ), the geometric mean $\mathrm{IC}_{50}$ estimated under the incubator atmospheric conditions $\left(5 \% \mathrm{CO}_{2}\right.$ and $\left.10 \% \mathrm{O}_{2}\right)$ was significantly lower for atovaquone (1.2 vs $2.1 \mathrm{nM}, \mathrm{p}=$ 0.0011) and higher for the quinolines: chloroquine (127 vs $94 \mathrm{nM}, \mathrm{p}<0.0001$ ), quinine (580 vs $439 \mathrm{nM}, \mathrm{p}<$ $0.0001)$, monodesethylamodiaquine (41.4 vs $31.8 \mathrm{nM}$, $\mathrm{p}<0.0001$ ), mefloquine (57.5 vs $49.7 \mathrm{nM}, \mathrm{p}=0.0011$ ) and lumefantrine (23.8 vs $21.2 \mathrm{nM}, \mathrm{p}=0.0044$ ) (Table 1 ). There was no significant difference of $\mathrm{IC}_{50}$ between the two conditions for dihydroartemisinin, doxycycline and pyrimethamine.

The $\mathrm{cpm}$ and $\mathrm{IC}_{50}$ values for each anti-malarial drug were highly and significantly correlated between the two conditions (Figure 2, 3 and 4).

Based on the thresholds of decreased susceptibility defined for the incubator atmospheric conditions (5\% $\mathrm{CO}_{2}$ and $10 \% \mathrm{O}_{2}$ ), the following discrepancies were observed: one of 21 strains (5\%) with $\mathrm{IC}_{50}>100 \mathrm{nM}$ for chloroquine [33] was $<100 \mathrm{nM}$ under Genbag $\left.{ }^{(}\right)$conditions; seven of 20 strains (35\%) with $\mathrm{IC}_{50}>800 \mathrm{nM}$ for quinine [34] was $<800 \mathrm{nM}$ under Genbag $\left.{ }^{(}\right)$conditions; two of 20 strains $(10 \%)$ with $\mathrm{IC}_{50}>30 \mathrm{nM}$ for mefloquine [35] was $<30 \mathrm{nM}$ under Genbag ${ }^{\circledR}$ conditions; four of 10 strains (40\%) with $\mathrm{IC}_{50}>80 \mathrm{nM}$ for monodesethylamodiaquine [36] was $<80 \mathrm{nM}$ under Genbag ${ }^{\circledR}$ conditions; and none of the 13 strains with $\mathrm{IC}_{50}>2,000 \mathrm{nM}$ for pyrimethamine [37] was $<2,000 \mathrm{nM}$ under Genbag ${ }^{\circledR}$ conditions. 
Table 1 In vitro activity of chloroquine, quinine, mefloquine, monodesethylamodiaquine, lumefantrine, pyrimethamine, atovaquone, dihydroartemisinin and doxycycline against 36 strains of Plasmodium falciparum under controlled incubator conditions $\left(10 \% \mathrm{O}_{2}\right)$ and Genbag ${ }^{\circledR}$ conditions $\left(15 \% \mathrm{O}_{2}\right)$

\begin{tabular}{|c|c|c|c|c|c|c|}
\hline \multirow[t]{2}{*}{ Compound } & \multirow[t]{2}{*}{$\mathrm{O}_{2} \%$} & \multicolumn{4}{|c|}{$\mathrm{IC}_{50}$} & \multirow[t]{2}{*}{ t-test $p$-value } \\
\hline & & Geometric mean & $95 \% \mathrm{Cl}$ & Min & Max & \\
\hline \multirow[t]{2}{*}{ Chloroquine } & 10 & $127 \mathrm{nM}$ & $77-211$ & 8 & 1032 & $<0.0001$ \\
\hline & 15 & $94 \mathrm{nM}$ & $61-146$ & 12 & 751 & \\
\hline \multirow[t]{2}{*}{ Quinine } & 10 & $580 \mathrm{nM}$ & $451-745$ & 153 & 1752 & $<0.0001$ \\
\hline & 15 & 439 nM & $336-573$ & 96 & 1288 & \\
\hline \multirow[t]{2}{*}{ Mefloquine } & 10 & $57.5 \mathrm{nM}$ & $50.7-65.3$ & 30.8 & 131.0 & 0.0011 \\
\hline & 15 & $49.7 \mathrm{nM}$ & $44.0-46.3$ & 26.4 & 113.0 & \\
\hline \multirow[t]{2}{*}{ Monodesethylamodiaquine } & 10 & $41.4 \mathrm{nM}$ & 28.8-59.6 & 4.7 & 379 & $<0.0001$ \\
\hline & 15 & $31.8 \mathrm{nM}$ & 21.8646 .2 & 4.0 & 357 & \\
\hline \multirow[t]{2}{*}{ Lumefantrine } & 10 & $23.8 \mathrm{nM}$ & 19.6628 .8 & 7.1 & 65.0 & 0.0044 \\
\hline & 15 & $21.2 \mathrm{nM}$ & $17.5-25.7$ & 7.2 & 72 & \\
\hline \multirow[t]{2}{*}{ Pyrimethamine } & 10 & $273 \mathrm{nM}$ & $88-852$ & 10 & 17025 & 0.0902 \\
\hline & 15 & $222 \mathrm{nM}$ & $67-735$ & 10 & 14938 & \\
\hline \multirow[t]{2}{*}{ Atovaquone } & 10 & $1.2 \mathrm{nM}$ & $0.8-1.8$ & 0.1 & 7.3 & 0.0011 \\
\hline & 15 & $2.1 \mathrm{nM}$ & $1.6-2.8$ & 0.2 & 11.7 & \\
\hline \multirow[t]{2}{*}{ Dihydroartemisinin } & 10 & $2.4 \mathrm{nM}$ & $2.0-2.9$ & 1.2 & 10.8 & 0.4088 \\
\hline & 15 & $2.4 \mathrm{nM}$ & $1.9-2.9$ & 1.0 & 14.3 & \\
\hline \multirow[t]{2}{*}{ Doxycycline } & 10 & $10.9 \mu \mathrm{M}$ & $9.8-12.1$ & 7.6 & 26.0 & 0.6771 \\
\hline & 15 & $10.8 \mu \mathrm{M}$ & $9.5-12.2$ & 6.3 & 24.5 & \\
\hline \multirow[t]{2}{*}{ cpm } & 10 & 2738 & $2628-2852$ & 671 & 17845 & $<0.0001$ \\
\hline & 15 & 2282 & $2189-2379$ & 623 & 12726 & \\
\hline
\end{tabular}

To reduce this difference in terms of anti-malarial susceptibility, a specific cut-off was estimated for each drug under Genbag ${ }^{\circledR}$ conditions by regression. The cut-off was estimated at $77 \mathrm{nM}$ for chloroquine (vs $100 \mathrm{nM}$ in $10 \% \mathrm{O}_{2}$ ), $611 \mathrm{nM}$ for quinine (vs $800 \mathrm{nM}$ ), $30 \mathrm{nM}$ for mefloquine (vs $30 \mathrm{nM}$ ), $61 \mathrm{nM}$ for monodesethylamodiaquine (vs $80 \mathrm{nM}$ ) and $1729 \mathrm{nM}$ for pyrimethamine (vs 2,000 nM). The cut-off was not re-estimated for drugs for which all the $\mathrm{CI}_{50}$ values were below the cutoff under controlled incubation conditions. For these drugs, median values were estimated: $2.9 \mathrm{nM}$ for atovaquone (vs $2.5 \mathrm{nM}$ in $10 \% \mathrm{O}_{2}$ ), $26 \mathrm{nM}$ for lumefantrine (vs $30 \mathrm{nM}$ ), $3 \mathrm{nM}$ for dihydroartemisinin (vs $3.0 \mathrm{nM}$ ) and $15 \mu \mathrm{M}$ for doxycycline (vs $15 \mu \mathrm{M}$ ).

The geometric mean ratio based on the chloroquinesusceptible reference clone $3 \mathrm{D} 7$ (strain $\mathrm{IC}_{50} / 3 \mathrm{D} 7 \mathrm{IC}_{50}$ ) obtained under the incubator atmospheric conditions $\left(5 \% \mathrm{CO}_{2}\right.$ and $\left.10 \% \mathrm{O}_{2}\right)$ was significantly higher for chloroquine ( $\mathrm{p}<0.0001)$, lumefantrine $(\mathrm{p}=0.0119)$, and dihydroartemisinin $(p=0.0006)$, but the ratio was significantly lower for mefloquine $(\mathrm{p}<0.0001)$ and doxycycline $(p=0.0002)$ (Table 2$)$. The geometric mean ratio based on the chloroquine-resistant reference clone W2 (strain $\mathrm{IC}_{50} / \mathrm{W} 2 \mathrm{IC}_{50}$ ) obtained under the incubator atmospheric conditions $\left(5 \% \mathrm{CO}_{2}\right.$ and $\left.10 \% \mathrm{O}_{2}\right)$ was significantly higher for chloroquine $(\mathrm{p}=0.0014)$, quinine $(\mathrm{p}=0.0006)$, monodesethylamodiaquine $(\mathrm{p}<0.0001)$, lumefantrine $(\mathrm{p}<0.0001)$, pyrimethamine $(\mathrm{p}=0.0026)$ and was significantly lower for dihydroartemisinin ( $\mathrm{p}<$ $0.0001)$ and doxycycline $(\mathrm{p}=0.0159)$ (Table 3$)$.

\section{Discussion}

The first works that assessed oxygen effects on $P$. falciparum asynchronous cultures had shown that microaerophilic environment allowed an optimal development of parasites [38]. Parasite growth failed under strict anaerobic conditions. Plasmodium falciparum possesses a functional mitochondrial respiratory chain with oxygen consumption [39]. It has been shown that there is some protector effect of $\mathrm{CO}_{2}$ at high oxygen concentration [38] through the medium $\mathrm{pH}$, the stability (between 7.2 and 7.45) of which is required for parasite growth [40]. The standard medium RPMI 1640, buffered with $25 \mathrm{mM}$ HEPES and $25 \mathrm{mM} \mathrm{NaHCO}$, was optimized to maintain the $\mathrm{pH}$ within the physiological range in an atmosphere containing $5 \% \mathrm{CO}_{2}$. Any modification of the $\mathrm{CO}_{2}$ concentration alters the $\mathrm{pH}$ of the medium, which in turn can influence the $\mathrm{IC}_{50}$ values of $\mathrm{pH}$-dependent drugs, such as quinolines, but not of those that are $\mathrm{pH}$-independent, such as pyrimethamine. Despite similar growth and tritium-labelled hypoxanthine incorporation rates in drug-free control wells, Shenyi He et al showed that increasing the $\mathrm{CO}_{2}$ concentration from $2.7 \%$ to $7 \%$ (with a constant $5 \% \mathrm{O}_{2}$ ) resulted in significantly higher 

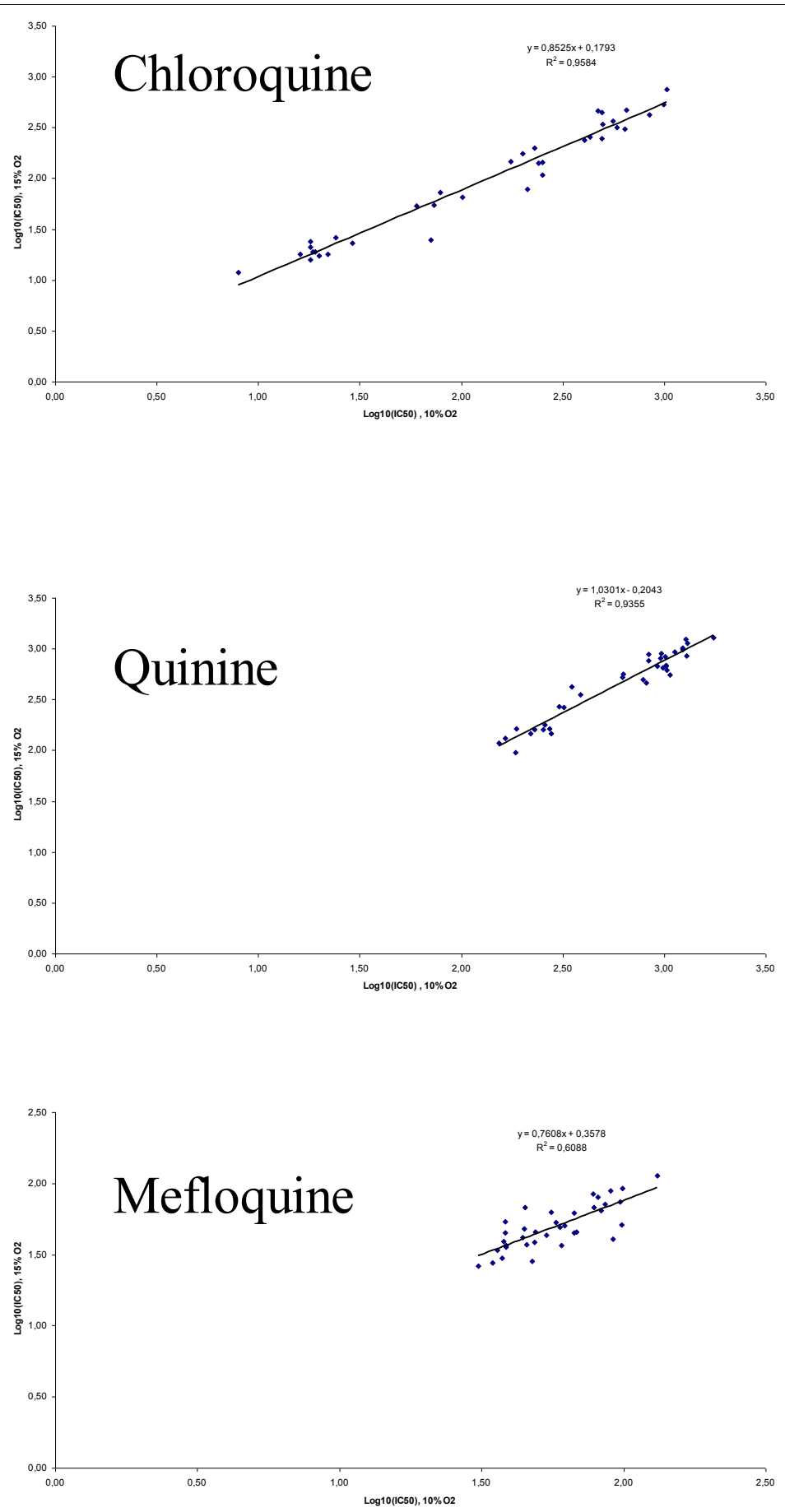

Figure 2 Correlation between log $\mathrm{IC}_{50}$ values of chloroquine, quinine or mefloquine, against 36 strains of Plasmodium falciparum under controlled incubator conditions $\left(10 \% \mathrm{O}_{2}\right)$ and Genbag ${ }^{\circledR}$ conditions $\left(15 \% \mathrm{O}_{2}\right)$.

chloroquine $\mathrm{IC}_{50}$ values [29]. The chloroquine-resistant $\mathrm{K} 1$ strain showed nine-fold greater chloroquine $\mathrm{IC}_{50}$ when the $\mathrm{CO}_{2}$ concentration was increased from 2.7 to $7 \%$ [29].

The atmospheric generators for capnophilic bacteria Genbag $\mathrm{CO}_{2}{ }^{\circledR}$ evaluated in this study release about $5 \%$
$\mathrm{CO}_{2}$ and reduce to $15 \% \mathrm{O}_{2}$ in $30 \mathrm{~min}$, according to the manufacturer's specifications (http://www.biomerieuxdiagnostics.com/servlet/srt/bio/clinical-diagnostics/dynPage?doc=CNL_PRD_CPL_G_PRD_CLN_62). The stated conditions are maintained at least for $48 \mathrm{~h}$. In this context, it seems that the significant differences in drug 


\section{Monodesethylamodiaquine}
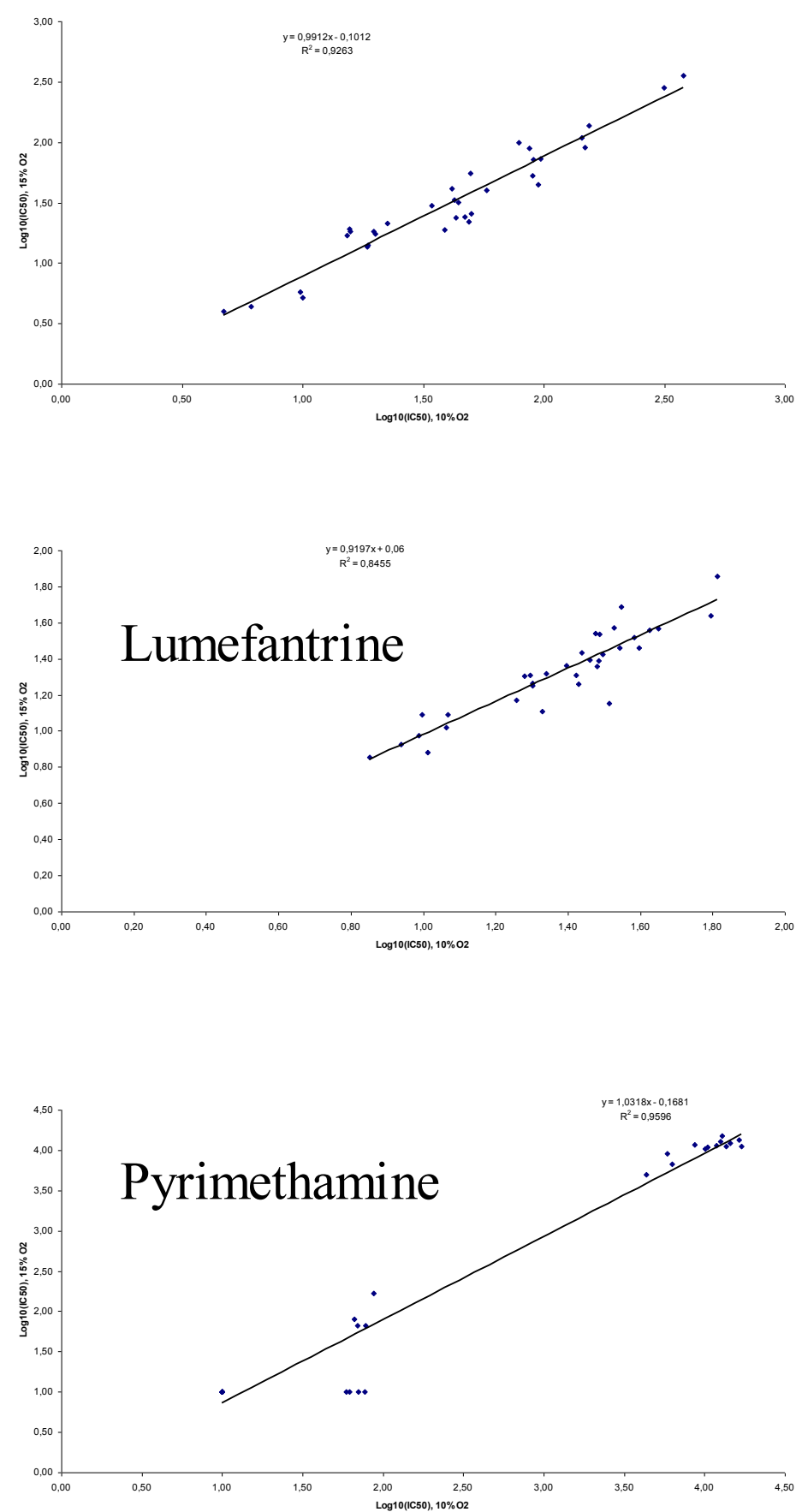

Figure 3 Correlation between log $\mathrm{IC}_{50}$ values of monodesethylamodiaquine, lumefantrine or pyrimethamine against 36 strains of Plasmodium falciparum under controlled incubator conditions $\left(10 \% \mathrm{O}_{2}\right)$ and $\mathrm{Genbag}^{\circledR}$ conditions $\left(15 \% \mathrm{O}_{2}\right)$.

$\mathrm{IC}_{50}$ values and growth level (cpm) between the two conditions, the incubator atmospheric conditions (5\% $\mathrm{CO}_{2}$ and $\left.10 \% \mathrm{O}_{2}\right)$ and the Genbag ${ }^{\circledR}$ conditions $\left(5 \% \mathrm{CO}_{2}\right.$ and $15 \% \mathrm{O}_{2}$ ), are due to the difference in $\mathrm{O}_{2}$ concentration.
The $\mathrm{IC}_{50}$ values of quinoline drugs, such as chloroquine, quinine, monodesethylamodiaquine, mefloquine and lumefantrine were significantly lower at $15 \% \mathrm{O}_{2}$ (Genbag $\mathrm{CO}_{2}{ }^{\circledR}$ ) than those at $10 \% \mathrm{O}_{2}$ (the incubator atmospheric conditions). This is in agreement with the 

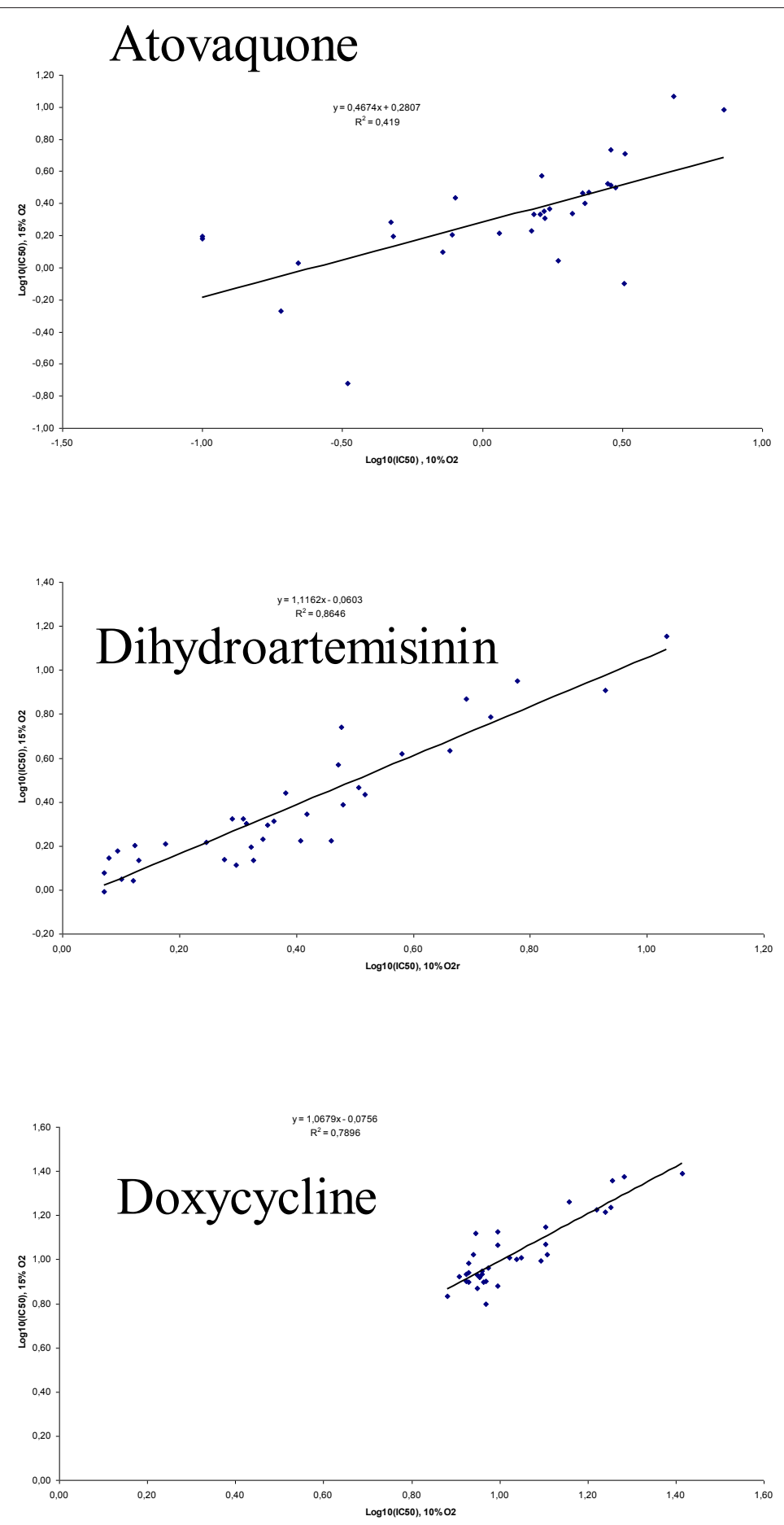

Figure 4 Correlation between log $\mathrm{IC}_{50}$ values of atovaquone, dihydroartemisinin or doxycycline against 36 strains of Plasmodium falciparum under controlled incubator conditions $\left(10 \% \mathrm{O}_{2}\right)$ and $\mathrm{Genbag}^{\circledR}$ conditions $\left(15 \% \mathrm{O}_{2}\right)$.

previous results that showed in $136 P$. falciparum fresh isolates from Comoros that the chloroquine $\mathrm{IC}_{50}$ values at $10 \% \mathrm{O}_{2}$ were significantly higher than those at $21 \%$ $\mathrm{O}_{2}$, with the means of $173.5 \mathrm{nM}$ and $121.5 \mathrm{nM}$, respectively [26]. Of particular interest among the 63 isolates that were resistant in vitro to chloroquine $\left(\mathrm{IC}_{50}>100 \mathrm{nM}\right)$ at $5 \% \mathrm{CO}_{2}$ and $10 \% \mathrm{O}_{2}$, was the observation that 17 were susceptible to chloroquine $\left(\mathrm{IC}_{50}<100 \mathrm{nM}\right)$ at $21 \%$ $\mathrm{O}_{2}$ [26]. In the present study, only one of 21 strains with chloroquine $\mathrm{IC}_{50}>100 \mathrm{nM}$ at $10 \% \mathrm{O}_{2}$ had $\mathrm{IC}_{50}<100 \mathrm{nM}$ 
Table 2 Ratio based on the chloroquine-susceptible reference clone 3D7 (strain IC $50 / 3 D 7$ IC 50 ) of chloroquine, quinine, mefloquine, monodesethylamodiaquine, lumefantrine, pyrimethamine, atovaquone, dihydroartemisinin and doxycycline against 36 strains of Plasmodium falciparum under controlled incubator conditions $\left(10 \% \mathrm{O}_{2}\right)$ and $\mathrm{Genbag}^{\circledR}$ conditions $\left(15 \% \mathrm{O}_{2}\right)$

\begin{tabular}{|c|c|c|c|c|c|c|}
\hline \multirow[t]{2}{*}{ Compound } & \multirow[t]{2}{*}{$\mathrm{O}_{2} \%$} & \multicolumn{4}{|c|}{$I C_{50} / 3 D 7 I C_{50}$} & \multirow[t]{2}{*}{ t-test $p$-value } \\
\hline & & Geometric mean & $95 \% \mathrm{Cl}$ & Min & Max & \\
\hline \multirow[t]{2}{*}{ Chloroquine } & 10 & 6.88 & $4.15-11.41$ & 0.40 & 55.80 & $<0.0001$ \\
\hline & 15 & 4.80 & $3.09-7.45$ & 0.60 & 38.30 & \\
\hline \multirow[t]{2}{*}{ Quinine } & 10 & 2.44 & $1.90-3.13$ & 0.65 & 7.39 & 0.2418 \\
\hline & 15 & 2.63 & $2.04-3.40$ & 0.66 & 7.24 & \\
\hline \multirow[t]{2}{*}{ Mefloquine } & 10 & 0.72 & $0.63-0.82$ & 0.39 & 1.64 & $<0.0001$ \\
\hline & 15 & 0.91 & $0.81-1.03$ & 0.49 & 2.089 & \\
\hline \multirow[t]{2}{*}{ Monodesethylamodiaquine } & 10 & 2.59 & $1.80-3.72$ & 0.29 & 23.69 & 0.5948 \\
\hline & 15 & 2.52 & $1.73-3.67$ & 0.32 & 28.33 & \\
\hline \multirow[t]{2}{*}{ Lumefantrine } & 10 & 0.90 & $0.74-1.09$ & 0.27 & 2.45 & 0.0119 \\
\hline & 15 & 0.81 & $0.67-0.98$ & 0.28 & 2.76 & \\
\hline \multirow[t]{2}{*}{ Pyrimethamine } & 10 & 27.31 & $8.75-85.21$ & 1.00 & 1703 & 0.0835 \\
\hline & 15 & 18.01 & $5.51-58.82$ & 1.00 & 1494 & \\
\hline \multirow[t]{2}{*}{ Atovaquone } & 10 & 0.88 & $0.59-1.31$ & 0.07 & 5.20 & 0.9187 \\
\hline & 15 & 0.89 & $0.67-1.19$ & 0.08 & 4.96 & \\
\hline \multirow[t]{2}{*}{ Dihydroartemisinin } & 10 & 1.53 & $1.27-1.85$ & 0.74 & 6.79 & 0.0006 \\
\hline & 15 & 1.31 & $1.04-1.64$ & 0.54 & 7.94 & \\
\hline \multirow[t]{2}{*}{ Doxycycline } & 10 & 1.21 & $1.09-1.35$ & 0.85 & 2.90 & 0.0002 \\
\hline & 15 & 1.37 & $1.21-1.55$ & 0.80 & 3.11 & \\
\hline
\end{tabular}

Table 3 Ratio based on the chloroquine-resistant reference clone W2 (strain IC ${ }_{50} / W 2 I C_{50}$ ) of chloroquine, quinine, mefloquine, monodesethylamodiaquine, lumefantrine, pyrimethamine, atovaquone, dihydroartemisinin and doxycycline against 36 strains of Plasmodium falciparum under controlled incubator conditions $\left(10 \% \mathrm{O}_{2}\right)$ and Genbag ${ }^{\circledR}$ conditions $\left(15 \% \mathrm{O}_{2}\right)$

\begin{tabular}{|c|c|c|c|c|c|c|}
\hline \multirow[t]{2}{*}{ Compound } & \multirow[t]{2}{*}{$\mathrm{O}_{2} \%$} & \multicolumn{4}{|c|}{$\mathrm{IC}_{50} / \mathrm{W} 2 \mathrm{IC}_{50}$} & \multirow[t]{2}{*}{ t-test $p$-value } \\
\hline & & Geometric mean & $95 \% \mathrm{Cl}$ & Min & Max & \\
\hline \multirow[t]{2}{*}{ Chloroquine } & 10 & 0.26 & $0.16-0.43$ & 0.02 & 2.12 & 0.0014 \\
\hline & 15 & 0.21 & $0.14-0.33$ & 0.03 & 1.71 & \\
\hline \multirow[t]{2}{*}{ Quinine } & 10 & 0.71 & $0.56-0.90$ & 0.19 & 2.04 & 0.0006 \\
\hline & 15 & 0.56 & $0.43-0.74$ & 0.12 & 1.65 & \\
\hline \multirow[t]{2}{*}{ Mefloquine } & 10 & 0.97 & $0.66-1.42$ & 0.43 & 1.82 & 0.6262 \\
\hline & 15 & 0.82 & $0.72-0.92$ & 0.43 & 1.85 & \\
\hline \multirow[t]{2}{*}{ Monodesethylamodiaquine } & 10 & 0.49 & $0.34-0.70$ & 0.06 & 4.47 & $<0.0001$ \\
\hline & 15 & 0.37 & $0.25-0.54$ & 0.05 & 4.14 & \\
\hline \multirow[t]{2}{*}{ Lumefantrine } & 10 & 1.25 & $1.03-1.52$ & 0.37 & 3.42 & $<0.0001$ \\
\hline & 15 & 0.94 & $0.78-1.15$ & 0.32 & 3.21 & \\
\hline \multirow[t]{2}{*}{ Pyrimethamine } & 10 & 0.03 & $0.01-0.10$ & 0.001 & 1.96 & 0.0026 \\
\hline & 15 & 0.02 & $0.01-0.07$ & 0.0008 & 1.26 & \\
\hline \multirow[t]{2}{*}{ Atovaquone } & 10 & 0.65 & $0.44-0.97$ & 0.05 & 3.85 & 0.8646 \\
\hline & 15 & 0.67 & $0.50-0.89$ & 0.06 & 3.71 & \\
\hline \multirow[t]{2}{*}{ Dihydroartemisinin } & 10 & 1.06 & $0.88-1.28$ & 0.51 & 4.70 & $<0.0001$ \\
\hline & 15 & 1.55 & $1.24-1.94$ & 0.65 & 9.41 & \\
\hline \multirow[t]{2}{*}{ Doxycycline } & 10 & 1.16 & $1.05-1.29$ & 0.81 & 2.78 & 0.0159 \\
\hline & 15 & 1.25 & $11.10-1.42$ & 0.73 & 2.85 & \\
\hline
\end{tabular}


at a concentration of $15 \%$. Some studies failed to show oxygen-dependent effects of chloroquine on $P$. falciparum in culture [27-29], but in these experiments less than four strains were tested. Shenyi He et al reported that the chloroquine $\mathrm{IC}_{50}$ values determined in a candle jar $(2.7 \%$ $\mathrm{CO}_{2}$ and $17.5 \% \mathrm{O}_{2}$ ) were similar to those determined in an incubator set at 2.7\% $\mathrm{CO}_{2}$ and $5 \% \mathrm{O}_{2}$ [27]. Lin et al observed similar chloroquine $\mathrm{IC}_{50}$ values with parasites incubated in $5 \% \mathrm{CO}_{2}$ and $5 \%$ or $15 \% \mathrm{O}_{2}$ generated by an AnaeroPack system [29].

In contrast, there was no significant difference of $\mathrm{IC}_{50}$ values between $10 \%$ and $15 \% \mathrm{O}_{2}$ conditions for doxycycline, dihydroartemisinin and pyrimethamine. Divo et al. reported that the anti-malarial activity of different cyclines was $\mathrm{O}_{2}$-dependent and higher at high $\mathrm{O}_{2}$ concentrations [27]. Nevertheless, this influence of $\mathrm{O}_{2}$ was not evident at $48 \mathrm{~h}$ but was profound at $96 \mathrm{~h}$. In the present study, $\mathrm{IC}_{50}$ values were only determined at $42 \mathrm{~h}$. The class of artemisinins contains an intramolecular peroxide bridge that is situated in the sesquiterperne lactone backbone structure. The anti-malarial potency of artemisinin was enhanced by oxygen and inhibited by oxygen radical scavengers [41,42]. The contrast between 10 and $15 \% \mathrm{O}_{2}$ is probably not high enough to observe any difference in dihydroartemisinin $\mathrm{IC}_{50}$ values.

Using the threshold values for in vitro resistance established under the controlled incubator conditions (5\% $\mathrm{CO}_{2}$ and $10 \% \mathrm{O}_{2}$ ), $0-40 \%$ of discordant results, depending on the test compounds, was obtained using the Genbag ${ }^{\circledR}$ incubation system. The effect of gas mixture on the results of chemosusceptibility assay should lead different laboratories involved in anti-malarial resistance survey to adapt a resistance threshold for each gas mixture or to use the same conditions to perform chemosusceptibility microtests. The cut-off value was reestimated for each drug in Genbag ${ }^{\circledR}$ conditions. The cut-off was estimated at $77 \mathrm{nM}$ for chloroquine (vs $100 \mathrm{nM}$ in $10 \% \mathrm{O}_{2}$ ), $611 \mathrm{nM}$ for quinine (vs $800 \mathrm{nM}$ ), $30 \mathrm{nM}$ for mefloquine (vs $30 \mathrm{nM}$ ), $61 \mathrm{nM}$ for monodesethylamodiaquine (vs $80 \mathrm{nM}$ ) and $1729 \mathrm{nM}$ for pyrimethamine (vs $2000 \mathrm{nM}$ ).

To reduce the effects of $\mathrm{O}_{2}$ on $\mathrm{IC}_{50}$ values between 10 and $15 \% \mathrm{O}_{2}$, the ratios of strain $\mathrm{IC}_{50} / 3 \mathrm{D} 7 \mathrm{IC}_{50}$ and strain $\mathrm{IC}_{50} / \mathrm{W} 2 \mathrm{IC}_{50}$ were calculated for each condition. Nevertheless, the mean ratios were not similar at $10 \%$ and $15 \% \mathrm{O}_{2}$ for most anti-malarial drugs, and the results depended on the reference clone.

\section{Conclusions}

The atmospheric generators for capnophilic bacteria Genbag $\mathrm{CO} 2^{\circledR}$ is an appropriate technology that can be transferred to the field for epidemiological surveys of drug-resistant malaria. The present data suggest the importance of the gas mixture on in vitro microtest results for anti-malarial drugs and the importance of determining the microtest conditions before comparing and analysing the data from different laboratories and concluding on malaria resistance.

\section{Acknowledgements}

This work was supported by the French Ministry of Defense. The views and opinions are those of the authors and do not purport to represent those of the French Ministry of Defense.

\section{Author details}

${ }^{1}$ Unité de Recherche en Biologie et Epidémiologie Parasitaires, Institut de Recherche Biomédicale des Armées - antenne de Marseille, Marseille, France. ${ }^{2}$ Unité de Recherche sur les Maladies Infectieuses et Tropicales Emergentes UMR 6236, Marseille, France. ${ }^{3}$ Centre national de référence du paludisme, Marseille, France.

\section{Authors' contributions}

$\mathrm{LKB}$ and $\mathrm{BP}$ conceived and designed the experiments. AP, EB, RA and DT performed the in vitro experiments. $C R$ and $B P$ analysed the data. $A P, L K B$, $\mathrm{CR}$ and $\mathrm{BP}$ wrote the paper. All authors read and approved the final manuscript.

\section{Conflict of interest}

The authors declare that they have no competing interests.

Received: 12 September 2010 Accepted: 14 January 2011 Published: 14 January 2011

\section{References}

1. Le Bras J, Musset $L$, Clain J: Les résistances aux médicaments antipaludiques. Med Maladies Infect 2006, 36:401-405.

2. Nosten F, White NJ: Artemisinin-based combination treatment of falciparum malaria. Am J Trop Med Hyg 2007, 77:181-192.

3. Eastman RT, Fidock DA: Artemisinin-based combination therapies: a vital tool in efforts to eliminate malaria. Nat Rev Microbiol 2009, 7:864-874.

4. Noedl H, Se Y, Schaecher K, Smith BL, Socheat D, Fukuda MM: Evidence of artemisinin-resistant malaria in western Cambodia. N Engl J Med 2008, 359:2619-2620.

5. Carrara VI, Zwang J, Ashley EA, Price RN, Stepniewska K, Barends M, Brockman A, Anderson T, McGready R, Phaiphun L, Proux S, van Vugt M, Hutagalung R, Lwin KM, Phyo AP, Preechapornkul P, Imwong M, Pukrittayakamee S, Singhasivanon P, White NJ, Nosten K: Changes in the treatment responses to artesunate-mefloquine on the Northwestern border of Thailand during 13 years of continuous deployment. PlosOne 2009, 4:4451.

6. Dondorp AM, Nosten F, Yi P, Das D, Phyo AP, Tarning J, Lwin KM, Ariey F Hanpithakpong W, Lee SJ, Ringwald P, Silamut K, Imwrong M, Chotivanish K, Lim P, Herdman T, An SS, Yeung S, Singhasivanon P, Day NPJ, Lindegardh N, Socheat D, White NJ: Artemisinin resistance in Plasmodium falciparum malaria. N Engl J Med 2009, 361:455-467.

7. Rogers WO, Sem R, Tero T, Chim P, Lim P, Muth S, Socheat D, Ariey F, Wongsrichanalai $C$ : Failure of artesunate-mefloquine combination therapy for uncomplicated Plasmodium falciparum malaria in southern Cambodia. Malar J 2009, 8:10.

8. Sibley $\mathrm{CH}$, Barnes Kl, Plowe $\mathrm{CV}$ : The rationale and plan for creating a World Antimalarial Resistance Network (WARN). Malar J 2007, 6:118.

9. Sibley $\mathrm{CH}$, Barnes Kl, Watkins WM, Plowe CV: A network to monitor antimalarial drug resistance: a plan for moving forward. Trends Parasitol 2008, 24:43-48, 2008.

10. WHO: Susceptibility of Plasmodium falciparum to antimalarial drugs. Reports on global monitoring 1996-2004. WHO/HTM/MAL/2005.110 Geneva: WHO; 2005.

11. Desjardins RE, Canfield CJ, Haynes JD, Chulay JD: Quantitative assessment of antimalarial activity in vitro by a semiautomated microdilution technique. Antimicrob Agents Chemother 1979, 16:710-718.

12. World Health Organisation: In vitro micro-test (Mark III) for the assessment of the response of Plasmodium falciparum to chloroquine, 
mefloquine, quinine, amodiaquine, sulfadoxine/pyrimethamine and artemisinin. WHO/CTD/MAL/97.20 Rev 22001 Geneva: WHO; 2001.

13. Rieckmann KH, Campbell GH, Sax LJ, Mrema JE: Drug sensitivity of Plasmodium falciparum. An in-vitro microtechnique. Lancet 1978, 1:22-23.

14. Wernsdorfer $\mathrm{WH}$ : Field evaluation of drug resistance in malaria. In vitro micro-test. Acta Trop 1980, 37:222-227.

15. Contreras CE, Rivas MA, Dominguez J, Charris J, Palacios M, Bianco NE, Blanca I: Stage-specific activity of potential antimalarial compounds measured in vitro by flow cytometry in comparison to optical microscopy and hypoxanthine uptake. Mem Inst Oswaldo Cruz 2004, 99:179-184.

16. Bacon JB, Latour C, Lucas C, Colina O, Ringwald P, Picot S: Comparison of a SYBR green I-based assay with a histidine-rich protein II enzyme-linked immunosorbent assay for in vitro antimalarial drug efficacy testing and application to clinical isolates. Antimicrob Agents Chemother 2007, 51:1172-1178.

17. Rason MA, Randriantsoa TA, drianantenaina H, Ratsimbasoa A, Menard D: Performance and reliability of the SYBR green I based assay for the routine monitoring of susceptibility of Plasmodium falciparum clinical isolates. Trans R Soc Trop Med Hyg 2008, 102:346-351.

18. Noedl H, Wernsdorfer WH, Miller RS, Wongsrichanalai C: Histidine-rich protein II: a novel approach to malaria drug sensitivity testing. Antimicrob Agents Chemother 2002, 46:1658-1664

19. Noedl H, Bronnert J, Yingyuen K, Attlmayr B, Kollaritsch H, Fukuda M: Simple histidine-rich protein 2 double-site sandwich enzyme-linked immunosorbent assay for use in malaria drug sensitivity testing. Antimicrob Agents Chemother 2005, 49:3575-3577.

20. Druilhe $P$, Moreno A, Blanc $C$, Brasseur PH, Jacquier P: A colorimetric in vitro drug sensitivity assay for Plasmodium falciparum based on a highly sensitive double-site lactate dehydrogenase antigen-capture enzymelinked immunosorbent assay. Am J Trop Med Hyg 2001, 64:233-241.

21. Kaddouri $\mathrm{H}$, Djimdé $\mathrm{A}$, Dama S, Kodio A, Tekete M, Hubert V, Koné A, Maiga H, Yattara O, Fofana B, Sidibe B, Sangaré CPO, Doumbo O, Le Bras J: Baseline in vitro efficacy of ACT component drugs on Plasmodium falciparum clinical isolates from Mali. Int J Parasitol 2008, 38:791-798.

22. Basco LK: Molecular epidemiology of malaria in cameroon. XX. Experimental studies on various factors of in vitro drug sensitivity assays using fresh isolates of Plasmodium falciparum. Am J Trop Med Hyg 2004, 70:474-480.

23. Pradines B, Spiegel A, Rogier C, Tall A, Mosnier J, Fusai T, Trape JF, Parzy D: Antibiotics for prophylaxis of Plasmodium falciparum infections: in vitro activity of doxycycline against Senegalese isolates. Am J Trop Med Hyg 2000, 62:82-85.

24. Pradines B, Hovette P, Fusai T, Atanda HL, Baret E, Cheval P, Mosnier J, Callec A, Cren J, Amalvict R, Gardair JP, Rogier C: Prevalence of in vitro resistance to eleven standard or new antimalarial drugs among Plasmodium falciparum isolates from Pointe-Noire, Republic of the Congo. J Clin Microbiol 2006, 44:2404-2408.

25. Dieng T, Bah IB, Ndiaye PM, Diallo I, Diop BM, Brasseur P, Mboup S, Wirth D, Ndir O: In vitro evaluation of the sensitivity of Plasmodium falciparum to chloroquine using the deli-microtest in region of Dakar, Senegal. Med Trop 2005, 65:580-583.

26. Briolant S, Parola P, Madamet-Torrentino M, Baret E, Mosnier J, Delmont J, Parzy D, Minodier P, Rogier C, Pradines B: Influence of oxygen on asexual blood cycle and susceptibility of Plasmodium falciparum to chloroquine: requirement of a standardized in vitro assay. Malar J 2007, 6:44.

27. Divo AA, Geary TG, Jensen JB: Oxygen- and time-dependent effects of antibiotics and selected mitochondrial inhibitors on Plasmodium falciparum in culture. Antimicrob Agents Chemother 1985, 27:21-27.

28. Lin Q, Onda T, Kano S, Masuda G, Suzuki M: In vitro susceptibility test of Plasmodium falciparum using a portable thermostat and $\mathrm{CO} 2$ gas generator. J Jpn Assoc Inf Dis 1999, 73:1099-1103.

29. He S, Saito-lto A, Tanabe K, Matsumura T: Plasmodium falciparum: Effective use of the $\mathrm{CO} 2-\mathrm{NaHCO} 3$ buffer system for evaluating chloroquine resistance. Exp Parasitol 2000, 94:121-124.

30. Lambros C, Vanderberg JP: Synchronization of Plasmodium falciparum erythrocytic stages in culture. J Parasitol 1979, 65:418-420

31. Bogreau H, Renaud F, Bouchiba H, Durand P, Assi SB, Henry MC, Garnotel E, Pradines B, Fusai T, Wade B, Adehossi E, Parola P, Kamil MA, Puijalon O, Rogier C: Genetic diversity and structure of African Plasmodium falciparum populations in urban and rural areas. Am J Trop Med Hyg 2006, 74:953-959.

32. Henry M, Diallo I, Bordes J, Ka S, Pradines B, Diatta B, M'Baye PS, Sane M, Thiam M, Gueye PM, Wade B, Touze JE, Debonne JM, Rogier C, Fusai T: Urban malaria in Dakar, Senegal: chemosusceptibility and genetic diversity of Plasmodium falciparum isolates. Am J Trop Med Hyg 2006, 75:146-151.

33. Le Bras J, Ringwald P: Plasmodium falciparum chemoresistance. The situation in Africa in 1989. Med Trop 1990, 50:161-162

34. Basco LK, Le Bras J: In vitro susceptibility of Cambodian isolates of Plasmodium falciparum to halofantrine, pyronaridine and artemisinin derivatives. Ann Trop Med Parasitol 1994, 88:137-144.

35. Hatin I, Trape JF, Legros F, Bauchet J, Le Bras J: Susceptibility of Plasmodium falciparum strains to mefloquine in an urban area of Senegal. Bull WHO 1992, 70:363-367.

36. Basco LK, Bras Le: In vitro activity of monodesethylamodiaquine and amopyroquine against African isolates and clones of Plasmodium falciparum. Am J Trop Med Hyg 1993, 48:120-125.

37. Basco LK, Ramiliarisoa O, Le Bras J: In vitro activity of pyrimethamine, cycloguanil and other antimalarial drugs against African isolates and clones of Plasmodium falciparum. Am J Trop Med Hyg 1994, 50:193-199.

38. Scheibel LW, Ashton SH, Trager W: Plasmodium falciparum: microaerophilic requirements in human red blood cells. Exp Parasitol 1979, 47:410-418.

39. Krungkrai J, Burat D, Kudan S, Krungkrai S, Prapunwattana P: Mitochondrial oxygen consumption in asexual and sexual blood stages of the human malarial parasite, Plasmodium falciparum. Southeast Asian J Trop Med Public Health 1999, 30:636-642.

40. Jensen MD, Conley M, Helstowski LD: Culture of Plasmodium falciparum: the role of pH, glucose, and lactate. J Parasitol 1983, 69:1060-1067.

41. Krungkrai J, Yuthavong Y: The antimalarial action on Plasmodium falciparum of qinghaosu and artesunate in combination with agents which modulates oxidant stress. Trans R Soc Trop Med Hyg 1987, 81:710-714.

42. Pradines B, Ramiandrasoa F, Fusai T, Hammadi A, Henry M, Briolant S, Orlandi-Pradines E, Bogreau H, Mosnier J, Baret E, Kunesch G, Le Bras J, Rogier C: Generation of free radicals and enhancement of hemininduced membrane damage by a catechol iron chelator in Plasmodium falciparum. J Biol Sc 2005, 5:463-471.

doi:10.1186/1475-2875-10-8

Cite this article as: Pascual et al:: Use of the atmospheric generators for capnophilic bacteria Genbag-CO2 for the evaluation of in vitro Plasmodium falciparum susceptibility to standard anti-malarial drugs. Malaria Journal 2011 10:8

\section{Submit your next manuscript to BioMed Central and take full advantage of:}

- Convenient online submission

- Thorough peer review

- No space constraints or color figure charges

- Immediate publication on acceptance

- Inclusion in PubMed, CAS, Scopus and Google Scholar

- Research which is freely available for redistribution

Submit your manuscript at www.biomedcentral.com/submit
C Biomed Central 